IRSH 55 (2010), Supplement, pp. I-26 doi:I0. I0I7/So020859010000477

(C) 2010 Internationaal Instituut voor Sociale Geschiedenis

\title{
Globalization, Environmental Change, and Social History: An Introduction
}

\author{
PETER BOOMGAARD \\ Koninklijk Instituut voor Taal-, Land-en Volkenkunde, Leiden \\ E-mail: boomgaard@kitlv.nl \\ MARJOLEIN'T HART \\ Faculteit der Geesteswetenschappen, Universiteit van Amsterdam \\ E-mail: M.C.tHart@uva.nl
}

Throughout the ages, the activities of humankind have weighed considerably upon the environment. In turn, changes in that environment have favoured the rise of certain social groups and limited the actions of others. Nevertheless, environmental history has remained a "blind spot" for many social and economic historians. ${ }^{.}$This is to be regretted, as changes in ecosystems have always had quite different consequences for different social groups. Indeed, the various and unequal effects of environmental change often explain the strengths and weaknesses of certain social groups, irrespective of their being defined along lines of class, gender, or ethnicity.

This Special Issue of the International Review of Social History aims to bring together the expertise of social and environmental historians. In the last few decades of the twentieth century, expanding holes in the ozone layer, global warming, and the accelerated pace of the destruction of the tropical forests have resulted in a worldwide recognition of two closely related processes: globalization and environmental change. ${ }^{2}$ The contributions to this volume provide striking case studies of such connections in earlier periods, revealing a fruitful interconnection between social and environmental history. This introduction provides a historiographical context for the essays that follow, focusing on the relevant notions connected

I. See Ted Steinberg, "Down to Earth: Nature, Agency, and Power in History", The American Historical Review, 107 (2002), pp. 798-820, 805.

2. Thomas E. Lovejoy and Lee Hannah (eds), Climate Change and Biodiversity (New Haven, CT, 2006); Alfred W. Crosby, Children of the Sun: A History of Humanity's Unappeasable Appetite for Energy (New York [etc.], 2006). 
with globalization and environmental change, and stressing the existing interactions between environmental and social history. We are particularly interested in the consequences of processes induced by globalization, how transnational forces and agents changed the socio-ecological space, and how that affected relationships between different classes in history.

\section{GLOBALIZATION AND GLOBAL HISTORY}

Globalization is a concept that needs further elaboration. The rise of the internet, the shifts in the power of sovereign national states, the intricate intertwining of global markets, and the enormous numbers of people migrating across regions and continents trying to escape wars, environmental degradation, or disasters have prompted several scholars to explain these recent trends using new definitions of globalization. The description by the political scientists David Held and Anthony McGrew nicely captures our understanding:

Simply put, globalization denotes the expanding scale, growing magnitude, speeding up and deepening impact of interregional flows and patterns of interaction. It refers to a shift or transformation in the scale in human organization that links distant communities and expands the reach of power relations across the world's major regions and continents. ${ }^{3}$

In history, as well as in the social sciences, debates abound on the timing or start of globalization. In contrast to some scholars, we are not inclined to use globalization as a term limited to a new epoch that started in the 1980 or $19905,{ }^{4}$ neither do we think that the rapid globalization in the nineteenth century precludes all early modern globalization, ${ }^{5}$ nor do we see a specific date (I 492 or I 57 I have been suggested, for example) in the early modern period from which globalization truly took off. ${ }^{6}$ Rather, we wish to look upon globalization as a set of highly variegated processes that can be labelled in different ways, ranging from "thick" to "thin" globalization and from "diffused" to "expanded". These categories are

3. David Held and Anthony McGrew, "The Great Globalization Debate: An Introduction”, in idem (eds), The Global Transformations Reader: An Introduction to the Globalization Debate, 2nd edn (Cambridge, 2003), p. 4. "Regions" refer to certain larger areas within a continent, usually encompassing several nation-states, for instance south-east Asia or the European Community.

4. Kenichi Ohmae, The End of the Nation State: The Rise of Regional Economies (New York, I995); Martin Albrow, "A New Decade of the Global Age, 1996-2006", Globality Studies Journal: Global History, Society, Civilization, 8 (2007), pp. I-26.

5. Kevin H. O’Rourke and Jeffrey G. Williamson, "When Did Globalisation Begin?", European Review of Economic History, 6 (2002), pp. 23-50.

6. Dennis O. Flynn and Arturo Giráldez, "Path Dependence, Time Lags and the Birth of Globalisation: A Critique of O'Rourke and Williamson”, European Review of Economic History, 8 (2004), pp. 8 I-108. 
derived from Global Transformations, the influential study by David Held et al. in which they observe variations in the extensity, the intensity, the velocity, and the impact of global connections. ${ }^{7}$

"Thick" globalization then refers to processes that share an expanding scale, growing magnitude, and an acceleration as well as a deepening of their impact. A case in point is the growing interconnection of the world markets in the late nineteenth century under the auspices of the British Empire. Thin globalization typically relates to developments that can be defined by an expanding scale while the other three characteristics are weak. A good example is the long-distance trade along the Eurasian silk route in the medieval period. The impact of diffuse globalization is likewise rather shallow, yet its velocity and intensity are high; the worldwide spread of Coca-Cola may serve as an illustration. Finally, expanded globalization refers to developments in which the impact is high, yet the intensity and velocity are limited, as represented by the colonization of Latin America and the Caribbean in the early modern period. This distinction in different categories allows us thus to investigate environmental impacts that can be substantial even before the rise of imperialism or other obvious "thick" globalizations.

In line with these thoughts, it would be preferable to speak about "globalizations" instead of one "globalization", not as a single process but as a multitude of uneven developments. ${ }^{8}$ Implicit in numerous conceptualizations of globalization is the assumption that it inevitably entails homogenization, that all societies will increasingly look the same. ${ }^{9}$ Although convergence is indeed often strong, globalization also leads to divergence, which is best illustrated perhaps by the division in world power. A set of elite groups in the core regions maintain excellent relations with the new nodes of power, while other groups and regions become increasingly marginalized. For example, when the world financial markets experienced rapid interconnection in the late twentieth century

7. David Held et al., Global Transformations: Politics, Economics, and Culture (Cambridge [etc.], 1999), pp. 17-23.

8. See also Wolf Schäfer, "From the End of European History to the Globality of World Regions: A Research Perspective", Globality Studies Journal: Global History, Society, Civilization, I (2006), pp. I-9, 6. This resembles the debates regarding modernization, in which it has become common ground to study "modernizations" instead of the one master trajectory in history towards modern society. The latter inevitably led to the misguided supposition of the superiority of the Western path of development. See Christopher Bayly, The Birth of the Modern World, I780-I9I4: Global Connections and Comparisons (Oxford, 2004); Julia Adams, Elisabeth S. Clemens, and Ann Shola Orloff (eds), Remaking Modernity: Politics, History, and Sociology (Durham, 2005).

9. Many historians follow this assumption, above all economic historians. See among others O'Rourke and Williamson, "When Did Globalisation Begin?", and Flynn and Giráldez, "Path Dependence, Time Lags and the Birth of Globalisation". 
the number of financial experts actually acquainted with the development was quite small; they were termed the "new economic hit men", and included major investors such as George Soros. ${ }^{10}$

The social scientist Manuel Castells stressed that globalization effectuates a sharpening of class distinctions and even the emergence of new classes. He observed that in the age of the internet, certain business managers moved rapidly towards the upper echelons of society, while at the bottom a new "fourth class" found itself deprived of digital ways to make money. Castells summarizes these trends as follows: elites are cosmopolitan and global, "ordinary people" remain oriented towards the local. ${ }^{\text {II }}$ Comparable processes are observed in different fields: for example, James Scott noted that in a Malaysian village the new profits of the green revolution went disproportionately to the wealthier farmers. ${ }^{\text {I2 }}$ Thus, marginalized people remain localized, strengthening divergence.

Divergence can also be the result of resistance to global trends. A growing consciousness of typically local and national interests results in movements wishing to stress differing and alternative paths, such as nationalist parties and fundamentalist Islam, to mention but a few. Movements that do not oppose globalization yet aspire to blend global tendencies within local traditions and solutions are called glocal, which can also reinforce divergent trends. ${ }^{13}$

Historians have also recognized the thick globalization of the last few decades of the twentieth century, above all its impact on the role of sovereign states. Not that the nation-state is withering away, but its functions have undergone major transformations, and historians have become more attentive to the workings of transnational trends and agents in earlier periods. ${ }^{14}$ As the global connections changed and intensified, as regional and intercontinental structures expanded, historians increasingly looked back on the development of their own nation-states as constructs that were strongly linked to a specific phase in world history. This stimulated the rise of a distinct group of world historians, as exemplified by the establishment of the Journal of World History in 1990. ${ }^{\text {Is }}$ Within world

ı०. Niall Ferguson, The Ascent of Money: A Financial History of the World (New York [etc.], 2008), pp. 314-327.

I I. Manuel Castells, The Rise of the Network Society. I: The Information Age: Economy, Society and Culture, 2nd edn (Cambridge [etc.], 2000), pp. $296 \mathrm{ff}$.

I 2. James Scott, Weapons of the Weak: Everyday Forms of Peasant Resistance (New Haven, CT, I985), pp. 56, 305 .

I3. Roland Robertson, Globalization: Social Theory and Global Culture (London, 1992).

I4. Patrick O’Brien, "Historiographical Traditions and Modern Imperatives for the Restoration of Global History", Journal of Global History, I (2006), pp. 3-39, 38.

I 5. Jerry H. Bentley, "A New Forum for Global History”, Journal of World History, I (1990), pp. iii-v, noted the increased awareness of historians regarding the changing position of the nation-state. 
history a further specialization occurred, with one group studying the world as a whole (world historians) and another focusing on global connections and comparisons across regions and continents (global historians). Although the Journal of World History harboured both species, the Journal of Global History was founded in 2006 with explicit reference to the second group. ${ }^{16}$ In calling attention to global connections, this Special Issue is strongly embedded within this latter trend of historiography, stressing further that globalization is a multifaceted process with both convergent and divergent trends that do not necessarily have to be "thick" to have a significant impact on localized societies.

\section{ENVIRONMENTAL HISTORY}

Since the start of the new millennium, environmental change has acquired an undisputed position in the historiography. It is invoked frequently by historians of all sorts and trades to explain the rise and decline of former civilizations such as that of the Fertile Crescent and of the Mayas. Also, short-term effects, such as weather conditions during major historical battles, have received increased attention. ${ }^{17}$ But this is a rather recent phenomenon. For a long time, history traditionally studied the actions of humans in the past, with only scant attention paid to the environment, which was more often than not viewed as immovable and unchangeable.

Nowadays, environmental history is quite generally defined as the study of the interaction between humans and nature, or between society and nature, in the past. ${ }^{18}$ The field received major stimuli with the growing awareness since the I960s and I970s of the impact of industrial pollution and nuclear waste. ${ }^{19}$ The historical world witnessed a major institutionalization with the establishment of the American Society for Environmental History in 1975 , followed by the publication of a journal, the Environmental Review (renamed Environmental History in the 1990s).

I6. William Gervase Clarence-Smith, Kenneth Pomeranz, and Peer Vries, "Editorial”, Journal of Global History, I (2006), pp. I-2; O’Brien, "Historiographical Traditions", p. 7.

17. Jared Diamond, Collapse: How Societies Choose to Fail or Succeed (New York, 2005); Ian Whyte, World Without End? Environmental Disaster and the Collapse of Empires (London [etc.], 2008).

18. Wolfgang Behringer, Kulturgeschichte des Klimas: Von der Eiszeit bis zur globalen Erwärmung (Munich, 2007), p. I I9; Timo Myllyntaus, "Environment in Explaining History: Restoring Humans as Part of Nature", in idem and Mikko Saikku (eds), Encountering the Past in Nature: Essays in Environmental History (Athens, OH, 200I), pp. I4I-160, I43-I45; Richard White, The Organic Machine: The Remaking of the Columbia River (New York, 1996), p. ix: "we cannot understand human history without natural history and we cannot understand natural history without human history. The two have been intertwined for millennia."

19. Alfred Crosby, "The Past and Present of Environmental History", The American Historical Review, I00 (1995), pp. I177-II89, II87-II88. 
Since then, North America has always been home to a prominent group of environmental historians. ${ }^{20}$ Europe followed in 1988 with the European Association for Environmental History, which published the Environmental History Newsletter before it became involved in the distribution of the journal Environment and History (published from 1995), of which Richard Grove was the founding editor, supported by colleagues from Europe, Africa, Asia, Australia, and the USA. Both journals set the academic standard for the field. The approach was strongly interdisciplinary, with contributions from historians, natural scientists, social scientists, and geographers, to mention only the most important. A couple of worldwide bestsellers rendered the field of study well known, notably Alfred W. Crosby's Columbian Exchange (1972) and Ecological Imperialism (1986); Donald Worster's The Ends of the Earth (1988); Clive Ponting's A Green History of the World (199I); Richard Grove's Green Imperialism (1995); Jared Diamond's Guns, Germs and Steel (1997); and John McNeill's Something New Under the Sun (2000). The creation of a new Italian historical journal in 2008, Global Environment, shows the strength and resilience of the environmental history approach. ${ }^{2 \mathrm{I}}$

Environmental history at its best shares three characteristic tendencies with global history: the long-term perspective, the transnational and transcontinental connections, and the interdisciplinary approach. First, many topics in environmental history require a long-term perspective. Pollution is often a matter of one or more generations, most ecological catastrophes have long-term repercussions, and erosion and climatic changes usually span decades or even centuries. Not surprisingly, the longue durée of the Annales tradition comes to the foreground again. ${ }^{22}$ Second, in spatial terms environmental history frequently transgresses national borders. Pollution does not stop at human-made frontiers; neither does erosion, let alone climate change. Like global historians, numerous environmental historians look beyond Eurocentric or Westerncentric approaches by focusing on developments in Asia, Africa, Latin America, Australasia, and even the oceans. The relationship between

20. J. Donald Hughes, What is Environmental History? (Cambridge, 2006); Sverker Sörlin and Paul Warde, "The Problem of the Problem of Environmental History: A Re-Reading of the Field and Its Purpose", Environmental History, I 2 (2007), pp. I07-1 30, 108.

2I. The bollettino called I Frutti di Demetra serves Italian-speaking environmental historians. The Low Countries have shared a Jaarboek voor Ecologische Geschiedenis since the I990s. See also Marjolein 't Hart, "Tussen dierenliefde en milieubeleid. Tien jaar ecologische geschiedschrijving in de Lage landen", Jaarboek voor Ecologische Geschiedenis, io (2007), pp. 23-44. 22. Fernand Braudel, La Méditerranée et le Monde Méditerranéen à l'époque de Philippe IIe (Paris, 1949); Emmanuel Le Roy Ladurie, Histoire du climat depuis l'an mil (Paris, 1967); Richard White, "American Environmental History: The Development of a New Historical Field", Pacific Historical Review, 54 (1985), pp. 297-335; J.R. McNeill, "Observations on the Nature and Culture of Environmental History”, History and Theory, 42 (2003), pp. 5-43, I4. 
colonialism/imperialism and ecological decline has received increased attention in the past two decades. ${ }^{23}$ Third, the interdisciplinary approach is strong not only among world historians, but also in environmental history as the latter incorporates insights from a range of fields, including biology, chemistry, geology, and archaeology. ${ }^{24}$ Characteristically, the youngest journal in the field of environmental history, Global Environment, carries the subtitle A Journal of History and Natural and Social Sciences.

As much of environmental history was and is linked to the growing concerns of the green social movement, the field is strongly problemoriented. Topics typically deal with the spread of epidemic disease, the consequences of climatic change, the far-reaching effects of natural disasters, the reduction in ecological diversity, and humans overburdening the ecosystem, as witnessed by air, soil, and water pollution and the impoverishment and erosion of the soil. ${ }^{25}$ Improved knowledge of El Niño climatic cycles has stimulated new research. ${ }^{26}$ Such environmental causes carry an enormous weight, but it is the social, economic, cultural, and political context that can explain the actual impact and consequences in full. Why are comparable disasters less destructive than others, why are some societies more resilient than others, why are certain classes or groups hurt more than others? Such questions call for a strong association of environmental studies with social history.

\section{SOCIAL HISTORY AND ENVIRONMENTAL STUDIES}

Despite the potential links between social and environmental history, the two fields still retain their own preferences, leaving several obvious interconnections underdeveloped. Most social historians tend to look at nature, at the environment, as a given, as a constant entity that needs no further research. On the other hand, many environmental historians often preoccupied with getting the necessary details from the natural sciences right - are inclined to look upon society as a homogeneous entity. The effects of disastrous floods or volcano eruptions, for example, are

23. David Arnold, The Problem of Nature: Environment, Culture and European Expansion (Oxford [etc.], 1996); Ramachandra Guha, The Unquiet Woods: Ecological Change and Peasant Resistance in the Himalaya, 2nd edn (Berkeley, CA, [etc.], 2000), p. xiii; John Richards, The Unending Frontier: An Environmental History of the Early Modern World (Berkeley, CA, [etc.], 2003); William Beinart and Lotte Hughes, Environment and Empire (Oxford, 2007).

24. J. Donald Hughes, "Three Dimensions of Environmental History", Environment and History, I4 (2008), pp. 319-330.

25. Myllyntaus, "Environment in Explaining History", p. I49.

26. Mike Davis, Late Victorian Holocausts: El Niño Famines and the Making of the Third World (London, 200I); Ross Couper-Johnston, El Niño: The Weather Phenomenon that Changed the World (London, 200I). 
frequently studied only for societies as a whole, without taking into account the different groupings within those societies. ${ }^{27}$ Even many of the environmentalist works within the widely acclaimed Annales School tended to overlook all sorts of societal differences.

Having said that, it should be pointed out that in several areas meaningful interaction can be found between social history and environmental studies. In this section we can stress only those that are of direct interest to this volume, centring, first, around the notion of vulnerability; secondly, imprudent environmental policies, related to the concept of unintended consequences; and, thirdly, social protests related to environmental policies (or the lack thereof), including the movement for environmental justice.

Vulnerability has recently become a major topic in environmental studies. Many disasters that seem purely "natural", such as earthquakes and floods, are often significantly aggravated by particular social policies or processes. Indeed, natural hazards turn into true disasters only if there is a high degree of vulnerability among a significant part of the population. Repeatedly, risks from natural catastrophes are greater for the poor, for racial and ethnic minorities, the less educated, and the politically powerless. ${ }^{28}$ At the same time, those groups at the lower end of the social hierarchy often suffer disproportionably from environmental degradation.

Studies related to El Niño have become commonplace in this regard. Worldwide droughts had occurred before, yet since the late eighteenth century considerable segments of the peasant class were increasingly living at subsistence levels in monoculture environments, with the result that any small fluctuation in harvests or grain prices had disastrous consequences. With the changing forms of production and consumption, what mattered above all was the question of which groups had access to the existing resources. ${ }^{29}$ In early nineteenth-century South Africa, for example, droughts destabilized above all the already marginalized indigenous

\footnotetext{
27. Alan Taylor, "Unnatural Inequalities: Social and Environmental Histories", Environmental History, r:4 (1996), pp. 6-19, 7; Stephen Mosley, "Common Ground: Integrating Social and Environmental History”, Journal of Social History, 39 (2006), pp. 91 5-933, 922.

28. Terry Cannon, "Vulnerability Analysis and the Explanation of 'Natural' Disasters", in Ann Varley (ed.), Disasters, Development and Environment (Chichester, 1994), pp. I3-31; Greg Bankoff, Georg Frerks, and Dorothea Hilhorst (eds), Mapping Vulnerability: Disasters, Development and People (London, 2004); Greg Bankoff, "Constructing Vulnerability: The Historical, Natural and Social Generation of Flooding in Metropolitan Manila”, Disasters, 27 (2003), pp. 224-238; Michael Dorsey, "Globalizing Justice: Against Environmental Racism in the Age of Globalization", in Natalia Arias and Ivonne Yánez (eds), Resistance: A Path Towards Sustainability (Quito, 2000), pp. 37-50; Ted Steinberg, Acts of God: The Unnatural History of Natural Disaster in America (New York, 2000).

29. Davis, Late Victorian Holocausts, pp. $277 \mathrm{ff} . ;$ Amartya Sen, Poverty and Famines: An Essay on Entitlement and Deprivation (Oxford, I982); on subsistence in a global context see Marcel van der Linden, Workers of the World: Essays Toward a Global Labor History (Leiden, 2008), pp. $324 \mathrm{ff}$.
} 
agrarian communities and, at the same time, strengthened the establishment of British rule over the territories. ${ }^{30}$

Climatic changes did not always need to have so much effect. The degree of vulnerability mattered, as Emanuela Guidoboni showed for the sixteenth-century Po Valley. There, communities had grown increasingly vulnerable due to the deforestation and cultivation of mountain slopes, while recurrent near-famine conditions had already weakened the peasant class too. In such circumstances the increase in rainfall during the "Little Ice Age" - which was not actually that exceptional - resulted in floods with an extremely high number of casualties. ${ }^{3 \mathrm{I}}$ Another example is the rapid spread of the plague in fourteenth-century Europe, which cannot be attributed solely to the deathly germs. Prior to the plague's arrival, living standards had been lowered, not least by a series of volcanic eruptions that impacted climatic circumstances and thus increased vulnerability. ${ }^{32}$

Yet vulnerability can also result in social movements that reduce such risks. In eighteenth-century colonial Mexico, floods brought about an increased awareness and willingness to cooperate among riverine populations. The organizations transcended even traditional lines of ethnicity and class. Likewise, Greg Bankoff has noted the emergence of mutual associations in twentieth-century Manila, in particular in areas prone to earthquakes and typhoons, which significantly enlarged the resilience of these communities. Such associations proved helpful in all spheres of life. ${ }^{33}$

A second concept that will be discussed in this context pertains to that of unintended consequences. Nowadays, Iceland is dominated by sterile wasteland, but at the time of its initial settlement wasteland accounted for only one-fifth of the surface area. Overgrazing and concomitant erosion rendered Iceland a harsh place to live, reducing its population from some 80,000 in the twelfth century to well below 30,000 in the eighteenth

30. Charles Ballard, "Drought and Economic Distress", Journal of Interdisciplinary History, 17 (1986), pp. 359-378.

31. Emanuela Guidoboni, "Human Factors, Extreme Events and Floods in the Lower Po Plain (Northern Italy) in the I6th Century", Environment and History, 4 (1998), pp. 279-308.

32. M.G.L. Baillie, "Putting Abrupt Environmental Change Back into Human History", in Paul Slack (ed.), Environments and Historical Change: The Linacre Lectures 1998 (Oxford, I999), pp. 46-75, 64-70.

33. Georgina H. Endfield, Isabel Fernández Tejedo, and Sarah L. O’Hara, "Conflict and Cooperation: Water, Floods, and Social Response in Colonial Guanajuato, Mexico", Environmental History, 9 (2004), pp. 22 I-247; Greg Bankoff, "Dangers to Going it Alone: Social Capital and the Origins of Community Resilience in the Philippines", Continuity and Change, 22 (2007), pp. 327-355, 34I; see also Enakshi Ganguly Thukral and Machindra D. Sakate, "Baliraja: A People's Alternative", in Enakshi Ganguly Thukral (ed.), Big Dams, Displaced People: Rivers of Sorrow, Rivers of Change (New Delhi, 1992), pp. I43-I54. Regarding situations in which water is a scarce resource - thus requiring cooperation, yet in which conflicts abound - see Helga Haftendorn, "Water and International Conflict", Third World Quarterly, 2I (2000), pp. 5I-68. 
century, from being rather well-to-do farmers to becoming poor cottiers and fishermen. Another famous example is the case of the Aral Sea. Driven by the short-term performance planning of the Soviet regime, aimed at achieving self-sufficiency of cotton production in central Asia, planners did not consider the possible long-term impact of their ideas. The consequences were disastrous for all communities in the area. ${ }^{34}$

In the social sciences, the concept of unintended consequences was popularized by Robert K. Merton as the "unanticipated consequences of purposive social action". Whereas humans usually act on the basis of opinion and estimate, most knowledge stems from comparable actions in the past. ${ }^{35}$ Here the particularities of the environment come to the forefront. The consequences of policies implicating the environment are frequently noticeable only after decades and are then often irreversible. Iceland's settlers did not realize the vulnerability of the island, as the environment in their home communities had not suffered from pasture at all. Decisions that worked well in the past may well be utterly destructive in later periods or in other settings; in this context the phrase "other things being equal" is often wrong as the environment is actually changing all the time.

A well-studied theme in this respect deals with conservation by colonial governments. In Green Imperialism Richard Grove established the growing awareness among colonial administrators of the possible detrimental effects of deforestation in particular. Within these colonial semi-scientific networks Grove even discovered the roots of Western environmentalism. ${ }^{36}$ Although the latter is a rather contested viewpoint, the fact remains that conservation schemes in the colonies preceded those in the homelands themselves.

Such conservation policies carried consequences, of course, that were at least partially unintended. ${ }^{37}$ The establishment of national parks and

34. Whyte, World Without End?, pp. I23, 201; Joachim Radkau, Nature and Power: A Global History of the Environment (Cambridge, 2008), pp. I 54, I66. For an excellent introduction to the environmental effects of colonization policies in the early modern period, see Richards, The Unending Frontier.

35. Robert K. Merton, "The Unanticipated Consequences of Purposive Social Action", American Sociological Review, I (1936), pp. 894-904, 899. For an insightful elaboration regarding unintended consequences in state policies, see James Scott, Seeing Like a State: How Certain Schemes to Improve the Human Condition Have Failed (New Haven, CT, 1998).

36. Richard Grove, Green Imperialism: Colonial Expansion, Tropical Islands Edens and the Origins of Environmentalism, I600-I860 (Cambridge, I995). On criticism regarding Grove's interpretations on the origins of environmentalism, see Radkau, Nature and Power, p. I28; S. Ravi Rajan, Modernizing Nature: Forestry and Imperial Eco-Development, I800-1950 (Oxford, 2006), p. 68.

37. Naturally, the effects of colonial policies were not always unintended. In the midnineteenth century, in order to improve the thrift of the colonized subjects, the British colonial secretary, Earl Grey, developed a tax system that was to fall in particular on those with the lowest incomes in the tropics. The scheme aimed to encourage positive working attitudes, as he 
national forests in the US drove numerous Native Americans from their traditional grounds. ${ }^{38}$ In twentieth-century Java the regulations to limit hunting implied that only those able to pay for a licence to hunt were allowed to do so, whereas large groups that previously had access were denied the right to those resources. ${ }^{39}$ In a similar fashion, the German colonial regime in northern Tanzania undermined the position of the wealthier indigenous farmers, thereby upsetting the social networks that had allowed many people to survive drought and famine in earlier periods. ${ }^{40}$ British engineers in India thought to improve the water management of the Indus with new dams and dykes and encouraged the founding of new settlements close to the river borders. However, those areas were also prone to flooding, which was the reason the local population had refrained from constructing houses there before. The result was increased vulnerability of the local population to natural hazards. ${ }^{4 \mathrm{I}}$

Such policies, well-intended or not, provoked at times violent protests. ${ }^{42}$ Complaints against the German colonial forest policy fed the Maji Maji rebellion of 1905-1907 in Tanzania. ${ }^{43}$ Prior to the emergence of the Zapatista movement in Mexico, the small peasants in Chiapas had suffered from

was convinced that tropical life made people too content with subsistence (in contrast to people in temperate zones). The new hut and poll taxes, in addition to direct taxes on "provision grounds" (the lots formerly assigned in the Caribbean by the master to have the slaves provide their own food, after emancipation usually in the hands of former slaves and their descendants) disproportionably burdened the locals. This kind of pseudo-scientific reasoning actually continued until the next century. See Philip D. Curtin, "The Environment Beyond Europe and the European Theory of Empire”, Journal of World History, I (1990), pp. I I I-I 50, I48-I 49.

38. Robert H. Keller and Michael F. Turek, American Indians \& National Parks (Tucson, AZ, 1998).

39. Peter Boomgaard, "Oriental Nature, Its Friends and Its Enemies: Conservation of Nature in Late-Colonial Indonesia, I 889-1949”, Environment and History, 5 (1999), pp. 257-292, 273. 40. John R. McNeill, Something New Under the Sun: An Environmental History of the Twentieth-Century World (New York [etc.], 2000), p. 207.

4I. Benjamin Weil, "The Rivers Come: Colonial Flood Control and Knowledge Systems in the Indus Basin, I840s-I930s", Environment and History, I 2 (2006), pp. 3-29, I4; see also Beinart and Hughes, Environment and Empire, p. 138 , on the British perception of irrigation as a cureall, even though famines persisted. On colonial policy to reduce vulnerability see Ravi Ahuja, "State Formation and 'Famine Policy' in Early Colonial South India”, Indian Economic and Social History Review, 39 (2002), pp. 35 I-380.

42. Richard Grove, Ecology, Climate and Empire: Colonialism and Global Environmental History, 1400-1940 (Cambridge, 1997), pp. 208-2 I I. Not always, though, as shown by Grace Carswell, "Soil Conservation Policies in Colonial Kigezi, Uganda: Successful Implementation and an Absence of Resistance", in William Beinart and Joann McGregor (eds), Social History E African Environments (Oxford [etc.], 2003), pp. I3 I-I 54, thanks largely to the fact that the colonial government used local chiefs to implement their policies - as a result, local conditions were taken into account more.

43. Thaddeus Sunseri, "Reinterpreting a Colonial Rebellion: Forestry and Social Control in German East Africa, I874-1915", Environmental History, 8 (2003), pp. 430-45 I. 
ecological marginalization. ${ }^{44}$ In South Africa, a series of protests followed the introduction of the government's policy to prevent the spread of the deadly East Coast fever. The best solution was the regular dipping of all cattle, preferably every week, to kill off the ticks that transmitted the disease. The new regulations, however, interfered strongly with the traditions of the inhabitants of Transkei, as cattle constituted their main form of accumulation and status, and dipping (at the state-owned tanks) increased the costs enormously (a fee per head of cattle was to be paid at every dipping), while trade and transport were hindered considerably. Numerous grievances were voiced - including the suspicion that the whites allowed the disease to rage deliberately in order to undermine African society, forcing young men to work in the new enterprises of the colonists. Violent attacks on state officials followed in $19 \mathrm{I} 4 .{ }^{45}$

The leading work in this field is Ramachandra Guha's path-breaking The Unquiet Woods. With the commercialization of the forests in the Himalayas, access to the means of production was radically altered. The British did not recognize communal rights but wished to deal only with individual farmers, which threatened, in particular, the traditional rights of grazing and fuel gathering. In the waves of protest that followed, official buildings were set fire to and the forest blocks targeted by the authorities for cutting down destroyed. After Indian independence, commercialization continued, however. A disastrous flood in 1970 fuelled the rise of a new movement that stressed the ruinous effects of deforestation. In the village of Reni, female peasants started to embrace trees in order to prevent them being felled in I974 (see Figure I). This non-violent means of protest was soon adopted elsewhere and the Chipko movement (chipko means "to hug") proved extremely successful, bringing commercial forestry in the area to a standstill. Thereafter, environmentalist movements in various other countries started to regard "Chipko" as a benchmark for inspiration, providing a bridge between localized protest and global action. ${ }^{46}$

In the US, the awareness of inequalities in access to the available resources, coupled with increased environmental degradation, nourished the movement for environmental justice in the I980s. Activists regarded environmental protection as an unalienable right of man, and called for sustainable development with equal access to existing resources. The participants,

44. Philip Howard, "The History of Ecological Marginalization in Chiapas", Environmental History, 3 (1998), pp. 357-377.

45. Colin Bundy, “'We Don't Want Your Rain, We Won't Dip': Popular Opposition, Collaboration and Social Control in the Anti-Dipping Movement, 1908-I6", in William Beinart and Colin Bundy, Hidden Struggles in Rural South Africa: Politics and Popular Movements in the Transkei and Eastern Cape, I890-1930 (London [etc.], 1987), pp. I9I-22 I.

46. Guha, The Unquiet Woods, pp. 27-56, I52-184, 198-199; Beinart and Hughes, Environment and Empire, p. 277. Chipko also inspired the early Greenpeace movement. 


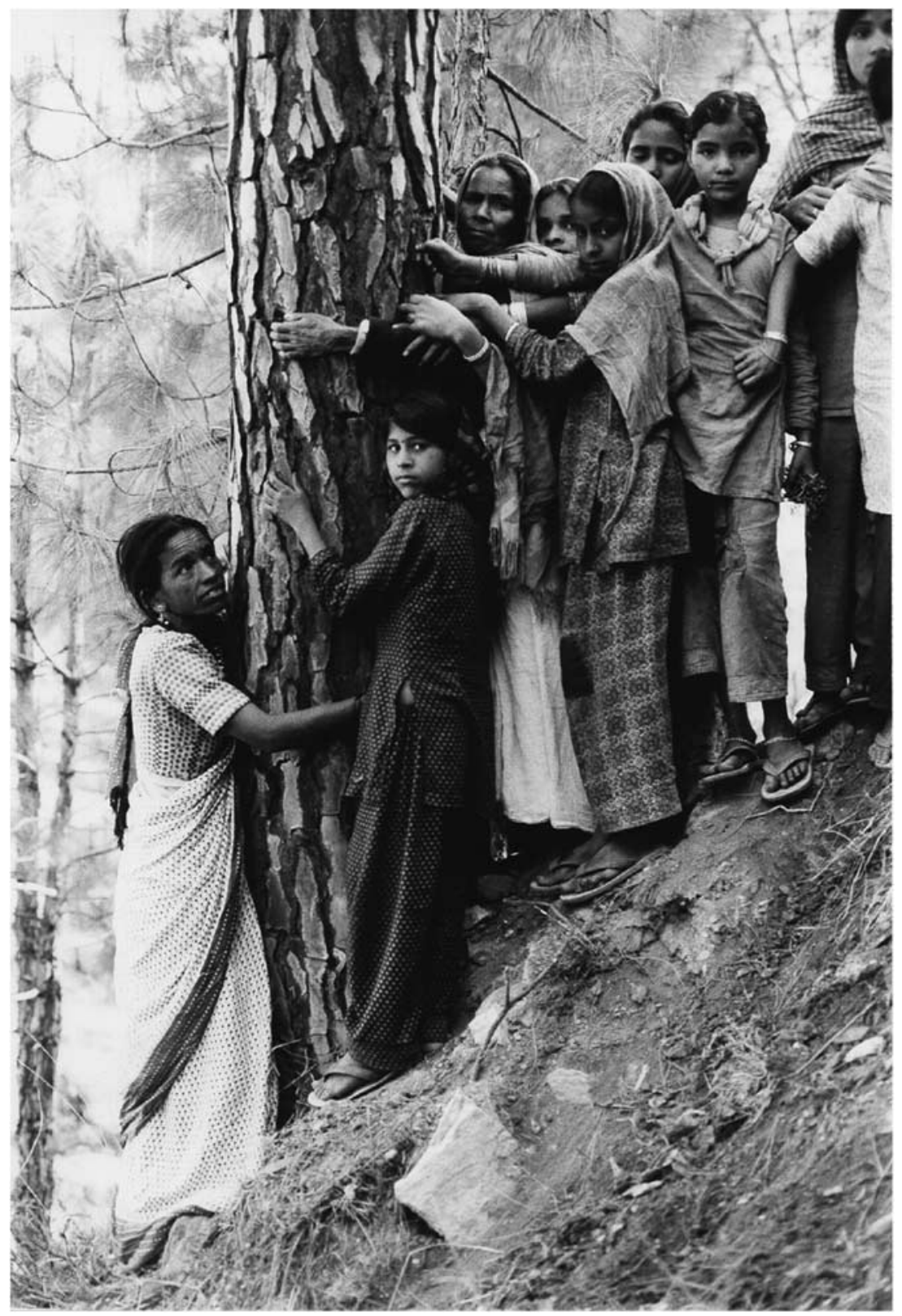

Figure I. Chipko movement: children and women embracing a tree, I987.

Photograph: The Right Livelihood Award. 
largely low-income women and blacks, differed from those in the mainstream environmental movement, which was predominantly middle-class, male, and white. ${ }^{47}$ The principles of environmental justice were picked up in other countries, and became a true global social movement. The indigenous rights movement swelled in the rg8os and gained a strong foothold in international forums in the r 990 s. $^{48}$

In turn, this movement inspired social historians to look at environmental degradation in relation to class, gender, and ethnicity. ${ }^{49}$ Some scholars focused on the impact of global economic trends on spatial allocations. The worldwide drive towards industrialization was so overriding that the entrepreneurial class frequently won in the struggles over the use of urban space, the local authorities failing or unwilling to implement existing environmental laws. ${ }^{\circ}$ Other scholars noted the consequences of global economic trends on trade-union policies. The major concessions that activists achieved at the Anaconda copper smelter in Montana (including the right to refuse to work in unsafe conditions without loss of pay) were curtailed with the global recession of the I970s. That same depression caused the collapse of the coalition between lower-class black activists and middle-class environmentalists in the metal works in

47. Giovanna Di Chiro, "Nature as Community: The Convergence of Environment and Social Justice", in William Cronon (ed.), Uncommon Ground: Toward Reinventing Nature (New York, I995), pp. 298-320, 300, 307 .

48. Joan Martinez-Alier, The Environmentalism of the Poor: A Study of Ecological Conflicts and Valuation (Cheltenham [etc.], 2002), pp. I68ff.; Arias and Yánez, Resistance: A Path Towards Sustainability; Beinart and Hughes, Environment and Empire, pp. $327 \mathrm{ff}$. Patricia Widener applied a truly transnational perspective in analysing the various protests along a pipeline owned by a multinational corporation in the oil exploitation in Ecuador: the Amazon, the Andes, and Pacific Coast; Patricia Widener, "Global Links and Environmental Flows: Oil Disputes in Ecuador", Global Environment Politics, 9 (2009), pp. 3 I-57. The brutal exploitation of the surrounding environment of two communities by the same international company is studied in Frank Meyer, "Expanding the Frontiers of Labour History: Kjartan Fløgstad's Synthesis of Local, Global, and Environmental History", International Review of Social History, 54 (2009), pp. 95-I09.

49. Carolyn Merchant, "Shades of Darkness: Race and Environmental History", Environmental History, 8 (2003), pp. 380-394; idem, "Gender and Environmental History", Journal of American History, 76 (1990), pp. I I 17-I I 2 I; Robert Bullard (ed.), Confronting Environmental Racism, Voices from the Grassroots (Boston, MA, I993); Dolores Greenberg, "Reconstructing Race and Protest: Environmental Justice in New York City", Environmental History, 5 (2000), pp. 223-250; Angela Gugliotta, "Class, Gender, and Coal Smoke: Gender Ideology and Environmental Injustice in Pittsburgh, I868-1914", Environmental History, 5 (2000), pp. 165-193. See also Shirley Bradway Laska, "Environmental Sociology and the State of the Discipline", Social Forces, 72 (1993), pp. I-I7.

50. Geneviève Massard-Guilbaud, "The Struggle for Urban Space: Nantes and ClermontFerrand, I830-1930", in Dieter Schott, Bill Luckin, and Geneviève Massard-Guilbaud (eds), Resources of the City: Contributions to an Environmental History of Modern Europe (Aldershot, 2005), pp. I I3-I3I. 
Gary, Indiana. ${ }^{\text {I }}$ Among geographers, the far-reaching social implications of globalizing capitalism and the new implications of "space" led to the emergence of critical geographical studies. ${ }^{52}$

\section{TRANSNATIONAL AGENTS, ENVIRONMENTAL CHANGE, AND SOCIAL CONSEQUENCES}

As argued earlier, globalization, though often perceived as a recent phenomenon, is actually a much older process, going back many centuries and even millennia. In a similar vein, people often associate environmental problems with the past fifty years or so, while it would not be difficult to provide examples of such problems, created by environmental change, originating several thousand years ago. Therefore, globalization and environmental change, often operating in tandem, are age-old but often underestimated historical processes. This volume presents case studies that touch on five major themes of great importance for environmental historians: species transmission, agricultural policies, energy usage, mining, and water management.

Possibly one of the oldest and most ubiquitous examples of environmental change is the spread of plants and animals from their region of origin to other parts of the globe (species transmission). Originally, the plants were mainly, if not exclusively, domesticated ones that produced food, fodder, oil, and fibres to be used for textile or rope, dyes, perfumes, and medicine, while the animals were also domesticated, and served humankind as food (or were at least a source of food), companions, means of transportation, traction, and as beasts of burden. Later, ornamental plants would come to play a considerable role in these plant migrations, as would trees that were to be planted in deforested regions. Perhaps the best-known episode in this global movement of plants and animals is the so-called Columbian Exchange, the term coined for the post-I 492 migration of crops and animals from the New World to Africa and Eurasia, and from the Old World to the New, as documented by Alfred Crosby. Thus, potatoes, tomatoes, and paprikas were introduced to Europe, maize (corn) and cassava to Africa, and maize, sweet potatoes, chillies, and tobacco to Asia, while wheat, rice, cattle, and horses came from the Old World to the New. ${ }^{53}$

51. Laurie Mercier, Anaconda: Labor, Community, and Culture in Montana's Smelter City (Urbana, IL, 200I), pp. 195-197; Andrew Hurley, Environmental Inequalities: Class, Race, and Industrial Pollution in Gary, Indiana, 1945-1990 (Chapel Hill, NC, I995), pp. I47-I 49.

52. David Harvey, Spaces of Capital: Towards a Critical Geography (New York, 2001); Andrew Herod, "The Practice of International Labor Solidarity and the Geography of the Global Economy", Economic Geography, 71 (1995), pp. 34I-363.

53. Alfred W. Crosby, The Columbian Exchange: Biological and Cultural Consequences of 1492 (Westport, CT, 1972); idem, Ecological Imperialism: The Biological Expansions of Europe, 900-I900 (Cambridge, I987). 
Such introductions were often deliberate attempts, undertaken by European merchant companies and colonizers, to generate a larger flow of commodities from the regions under their control. However, the introduction of various carbohydrate-rich crops, such as cereals, and roots and tubers, is less well documented. Sometimes they were introduced in order to increase food security in areas where the Europeans aimed at a shift from labour-intensive food crops to equally labour-intensive export crops. More often, we do not know when and why seeds or cuttings from these crops were brought over to other areas, and we can only conclude that at a certain moment they began to be successfully cultivated in regions where they did not occur before. ${ }^{54}$

The environmental changes brought about by these plant and animal migrations were far-reaching. Landscapes changed beyond recognition. This was the case, for instance, when the new crops were cultivated commercially on large estates (plantations), as happened with sugar, coffee, cacao, tobacco, tea, rubber, and oil palm. But it also occurred in the case of cereals such as maize, which now covers, often almost as a monoculture, large areas in Eurasia where smallholder agriculture is predominant. In many cases, the new crops "colonized" hitherto uncultivated areas, particularly in the ecologically vulnerable uplands, which often led to deforestation and erosion. Similar environmental damage was caused in areas where large ruminants had been absent before their postI492 introduction. 55

The increasing popularity of environmental history and the recent trend towards global warming have led to a growing emphasis in historical studies on climate change in the past, and a gradually warmer climate between I 670 and 1800 is now sometimes cited as the main factor behind increased rates of population growth. ${ }^{56}$ However, it is also likely that the newly introduced, "alien" food crops, with high carbohydrate content, often yielding more calories per unit of land and/or per unit of labour, or being cultivated in places that were too cold or too steep for other crops, contributed to these higher growth rates, probably at least partly also because their presence led to crop diversification, and therefore lower famine risk. ${ }^{57}$ Thus, the Columbian Exchange may have contributed to

54. Peter Boomgaard, "Maize and Tobacco in Upland Indonesia, I600-1940", in Tania Murray Li (ed.), Transforming the Indonesian Uplands: Marginality, Power and Production (Amsterdam, 1999), pp. 45-78; Peter Boomgaard, "In the Shadow of Rice: Roots and Tubers in Indonesian History, I 500-1950”, Agricultural History, 77 (2003), pp. 582-610.

55. Richards, The Unending Frontier.

56. Anthony N. Penna, The Human Footprint: A Global Environmental History (Chichester, 2010), pp. 98-103.

57. See for instance Geoffrey C. Gunn, First Globalization: The Eurasian Exchange, I 500-I800 (Lanham, MD, [etc.], 2003), p. 204; Behringer, Kulturgeschichte des Klimas, p. 226; Cormac Ó Gráda, Famine: A Short History (Princeton, NJ, 2009), pp. 70-72. 
higher population densities, during an epoch in which population growth rates and densities were generally speaking relatively low, which was the usual state of affairs in most areas of the world prior to I950.

Some transmissions were truly unintended, such as the mosquito that travelled with the slave ships to the Caribbean sugar-plantation economies carrying the deadly Yellow Fever. The blacks themselves had inherited immunity to this disease, but the Europeans had not. The hidden transmission caused the death of numerous British soldiers sent to these islands to crush slave resistance, and furthered the cause of the Haitian rebels in the early nineteenth century: as soon as the spring rains facilitated the multiplication of the mosquitoes, French soldiers sent by Napoleon were decimated by Yellow Fever. ${ }^{58}$

In this volume, we encounter several examples of species transmission. It is the main theme of Bennett's essay on the introduction of eucalyptus species, originally trees growing in Australia, into South Africa, India, and Thailand, mainly between I 850 and 2000 . The trees were often introduced because forestation or reforestation was deemed necessary by functionaries of the (indigenous, colonial, and postcolonial) forest departments, and eucalypts were fast-growing species. Bennett argues that the trees had many disadvantages, particularly for local smallholders, of which a voracious appetite for water was one. Thus, the continued planting of these trees sparked off local protest movements, for instance in Thailand in recent times. Both the need for reforestation and the fact that so many forestry experts opted for the same solution can be seen as features of the globalization process. ${ }^{59}$

Another example of the introduction of alien species is to be found in the essay by Halikowski Smith, dealing with the "discovery" and colonization of the mid-Atlantic islands - the Canary Islands, Madeira, the Azores, Cape Verde - in the fifteenth and sixteenth centuries by the Portuguese and the Spaniards. Various "new" crops were introduced, including sugar cane and grapes as commercial crops, and various cereals

58. J.R. McNeill, Mosquito Empires: Ecology and War in the Greater Caribbean, 1620-19I4 (New York [etc.], 2010). Equally unintended was the spread of the Aedes albopictus, also known as the Asian tiger mosquito, carrying a number of viruses that were causative agents of epidemic diseases, including Dengue Fever, which can be life-threatening and for which no vaccine yet exists. Several decades ago, this disease was typically found in tropical areas only. But with the globalization of the used-tyres economy, the Asian tiger mosquito seems to have been a frequent passenger in the tyre casings. Rubber tyres thus spread Dengue Fever worldwide. Donald Kennedy and Marjorie Lucks, "Rubber, Blight, and Mosquitoes: Biogeography Meets the Global Economy", Environmental History, 4 (1999), pp. 369-383, 377; Wouter van der Weijden, Rob Leewis, and Pieter Bol, Biological Globalisation: Bio-Invasions and their Impacts on Nature, the Economy and Public Health (Utrecht, 2007), pp. I57-1 58.

59. Eucalypts were planted not only in a colonial or tropical context, but also in Europe, for instance in Spain and Italy. 
as subsistence crops (though some of these were exported, creating food shortages). The introduction of these crops was preceded by the largescale and rapid deforestation of the islands; the introduction of livestock had similar effects. These islands were usually underpopulated - if not empty - when the European settlers arrived. However, the environmental effects of rapid deforestation, brought about not only by the free settlers themselves but also by black slaves and white convict and indentured labourers often imported to the islands in order to speed up the landclearing process, and the combination of too many hectares planted with export crops and a lack of food crops, caused overpopulation and emigration. Soon, the production of sugar on these islands was no longer profitable, and sugar cane migrated onwards to Brazil and later to the Caribbean. ${ }^{60}$ It may be mentioned as an aside that deforestation was a problem that would continue to plague the islands, and for which on Madeira eucalypts were planted as a remedy. ${ }^{6 \text { I }}$

The essay by Horan takes the story up on the eighteenth-century Caribbean sugar plantations, where the slave population was now having problems very similar to those experienced a few centuries earlier on the mid-Atlantic islands. French sugar planters - and presumably those of other nationalities as well - were having so much trouble feeding their black slaves adequately, largely because sugar took up so much space (and time), that the production of food crops, or the collection of foodstuffs in the uncultivated areas, including hunting, was at times insufficient. This situation led to undernourishment, malnutrition, famine, high morbidity, and high mortality. Thus the introduction of a new crop - sugar - was the cause of the introduction of black slaves while the expansion of sugar led to high mortality among the slaves and therefore to the perpetuation of the slave trade. The sustained and increasing supply of cane sugar from the West Indies (and elsewhere) was, of course, a response to increasing global demand. ${ }^{62}$

The food supply problem, which appears to have become more acute as time went by, no doubt because sugar became increasingly a monoculture and covered larger sections of the islands (although there were considerable differences between the islands), lies at the root of the famous

60. José Padua established an intricate relationship between the exploitative views connected with slavery and racism and the rigorous deforestation of the tropical forests in Brazil: to the colonizers, both labour and environment seemed inexhaustible resources; José Augusto Padua, "European Colonialism and Tropical Forest Destruction in Brazil", in J.R. McNeill, J.A. Padua, and Mahesh Rangarajan (eds), Environmental History: As if Nature Existed (Oxford, 2010), pp. I30-I 50.

61. Personal observation of one of the authors.

62. Sidney W. Mintz, Sweetness and Power: The Place of Sugar in Modern History (New York, 1985); Richards, The Unending Frontier, pp. 41 2-460. 
story - not told by Horan - of Captain William Bligh, who, in I776, was sent out by London to Tahiti, in the Pacific, to collect breadfruit plants which then were to be transported to the Caribbean. This tree took little time to grow, its carbohydrate-rich fruit was easily harvested, and could feed many people; the plant was therefore ideal for the Caribbean situation (see Figure 2). The journey, however, ended in the infamous mutiny on the Bounty, and Bligh was forced to leave his ship in a boat. He lived to tell the tale, however, and returned to the Pacific many years later, taking 347 breadfruit plants to the West Indies, where they became a success. ${ }^{6}$ The comparison is perhaps not entirely fair, but it would appear that while, according to Horan, the French planters did not do much more than complain that the French merchants who monopolized the trade with the French West Indies were involved in a conspiracy ("famine plot") against the colonists in order to keep food prices high, the British authorities actually tried to do something about it.

Changing agricultural policies and practices should be mentioned as the second theme that goes to the heart of environmental history. Throughout history, rulers and governments have attempted to influence their peasantry and their larger landowners (aristocracy) with regard to the crops they were growing, the time they started planting, cropping and land-use patterns, and the places where new arable lands were cleared. It goes without saying that such attempts - if successful - changed the landscape considerably. ${ }^{64}$

Many of the essays included in this volume address the environmental effects of agricultural developments in the remote or recent past to a greater or lesser extent - Halikowski Smith, Morera, Horan, Kanda, and Nascimento and Becker. However, only in the contribution written by Thompson are changing agricultural policies and practices the main theme. He discusses changes in agricultural practices, largely as a consequence of colonial and postcolonial policies, in post-I930 Rhodesia/ Zimbabwe. Thompson shows how measures in agriculture, designed by the colonial agricultural extension services, and backed by the colonial civil service, in addition to better access to markets through the construction of roads, led to the introduction of new technology (ploughs for example), new cropping and land-use patterns, and shifts from subsistence to market crops. These policies represented globally held notions, or at

63. See for instance Gunn, First Globalization, p. 76.

64. A few examples are Carville Earle, "The Myth of the Southern Soil Miner: Macrohistory, Agricultural Innovation, and Environmental Change", in Donald Worster (ed.), The Ends of the Earth: Perspectives on Modern Environmental History (Cambridge, I988), pp. 175-2 I0; Clive Ponting, A Green History of the World (London, I991), pp. 37-1 16; Helen Wheatly (ed.), Agriculture, Resource Exploitation, and Environmental Change (Aldershot, 1997); McNeill, Something New Under the Sun, pp. 2 I 2-227; J. Donald Hughes, An Environmental History of the World: Humankind's Changing Role in the Community of Life (London, 2002), pp. 30-140. 


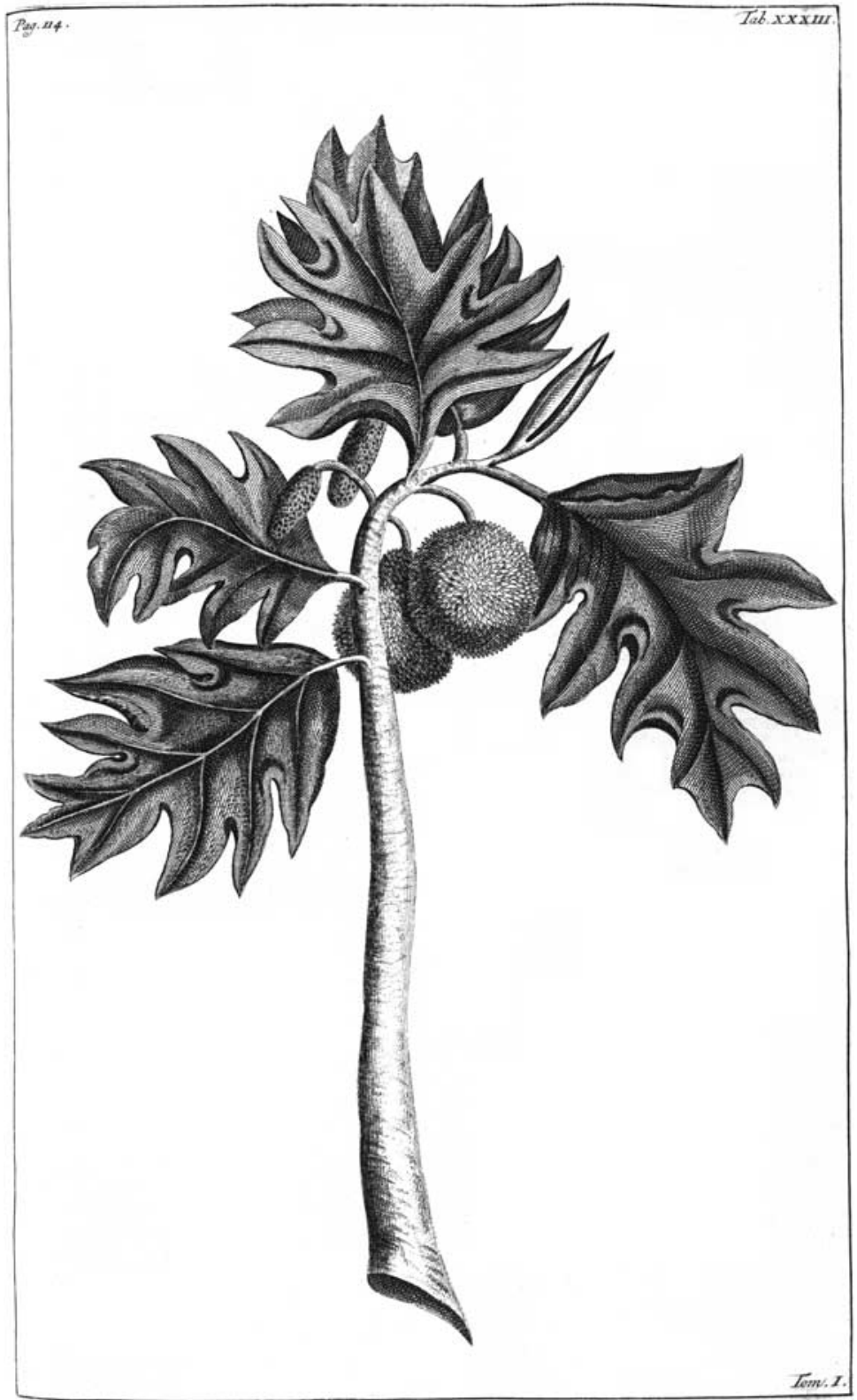

Figure 2. This is the breadfruit tree (Artocarpus altilis), which was taken by Captain William Bligh from the Pacific to the Caribbean in the late eighteenth century. Here it was planted in order to feed the slaves on the plantations.

Source: G.E. Rumphius, Herbarium Amboinense/Het Amboinsche Kruid-boek (Amsterdam, Changuion [etc.], I74I-I750), I, plate xxxiii, opposite p. II 4 .

Courtesy KITLV, Leiden. 
least notions held by most Western agronomists, regarding changes that would improve yields in tropical agriculture, standards of living, and local food security (and would probably produce higher tax returns as well). In Rhodesia, all this occurred in combination with the land-segregation policies of the colonial regime.

Many of the new practices represented environmental change, as was the case with more "waste" land coming under cultivation, fields with single crops taking the place of intercropped arable lands, the application of manure, and the increased need for weeding. These shifts in agricultural practices, in turn, changed specific rights, obligations, and workloads, leading to gender and generational conflicts, and new relations between men and women, and fathers and sons. ${ }^{65}$

Another major theme in environmental history is the use of energy, and the way in which, on the one hand, increasing energy consumption led to environmental changes, while on the other hand environmental changes (such as deforestation) led to a shift from biomass (firewood, charcoal, peat, straw, grass, cow dung) to fossil fuels (coal, oil, gas). Although locally some types of biomass fuel became scarce at an early stage, it is in principle a renewable energy source, while fossil fuels are not - they will eventually run out.

Britain was the first country where the growing use of firewood and charcoal caused the forest cover to shrink so much that by the late eighteenth century there was no longer sufficient biomass fuel, which had also become very expensive. This led to a shift from firewood and charcoal to coal for many households and industrial processes. At the same time, differential access to the new fuel resources hardened existing class distinctions. ${ }^{66}$ The shift played an important role in the Industrial Revolution and in "the Rise of the West". In the twentieth century, a gradual shift from coal to oil occurred, and the availability of cheap oil led to high economic growth rates. Fuel consumption, therefore, is an important theme in environmental history,

65. Recurrently, colonial administrators undervalued the productive role of female peasants. In the land settlements schemes of Malawi in the I950s, the administrators tried to abolish matrilocality, which had long ensured women's access to land, as they regarded it as an obstacle to growth by preventing the rise of a male breadwinner class; John McCracken, "Conservation \& Resistance in Colonial Malawi: The 'Dead North' Revisited", in Beinart and McGregor, Social History \& African Environments, pp. I55-174, I68. In Kenya, women resisted official orders to plant maize only and continued to grow drought-resistant millet: Beinart and Hughes, Environment and Empire, p. 287.

66. Wrigley stated that class positions were henceforth no longer defined merely by access to land and capital goods, but also by access to the new energy resources; E.A. Wrigley, "Meeting Human Energy Needs: Constraints, Opportunities, and Effects", in Slack, Environments and Historical Change, pp. 76-95, 88. Wrigley noted also that the shift from biomass to fossil fuels rendered poverty more than before a social-political issue. In pre-industrial societies, access to the energy stored in the environment was limited, which reduced the possible range of actions. With the new energy systems, it had become possible to reduce poverty significantly. Failure or unwillingness to reduce poverty thus became, more than before, a moral issue. 
and many scholars have emphasized increasing and changing energy consumption as a driving force in history. ${ }^{67}$ Moreover, in numerous instances collecting biomass fuel (together with land clearing for agriculture) caused, as we have seen, deforestation, while the production of fossil fuel led in many cases to ruined landscapes and pollution. Production and consumption of all types of fuel feature prominently in the global warming debate.

Fuel consumption is addressed, as an aside, in various contributions in this volume, for instance by Halikowski Smith, Horan, and Bennett, but only in Kanda's essay is it the main theme. Her essay deals with the ways in which changes in local and global demand for salt and other commodities influenced the use of biomass and fossil fuels, the demand for which, in turn, caused problems for the salt makers in India in the first half of the nineteenth century. Salt-making was a British "colonial” - East India Company - monopoly, which had to compete for fuel with other types of "industrial" enterprise promoted, undertaken, or monopolized by the Company (opium, silk, indigo, sugar cane), and with modern water transport - steamers - introduced by the British. This competition led to scarcity and a rise in fuel prices, but local circumstances dictated what type of fuel would become scarce - sometimes it was locally produced coal, but in other places firewood was more expensive and harder to obtain than coal, while elsewhere markets developed for grasses, stalks, and straw, which until then had usually been "free goods". ${ }^{68}$

In the I 840 s, many Indian salt makers stopped being active in this trade because the salt they produced had become too expensive due to the high fuel prices. Not much later, cheap salt would be imported from Britain. Thus the local scarcity of biomass fuels led, as it did in Britain earlier, to coal mining, but the shift from biomass to coal was much more localized and had totally different economic and social consequences than it did in Britain. Part of the explanation for these differences is no doubt that India was a quasi-colony around that time, while England was not. ${ }^{69}$

67. I.G. Simmons, Changing the Face of the Earth: Culture, Environment, History (Oxford, 1989); Ponting, A Green History of the World, pp. 267-294; McNeill, Something New Under the Sun; Edmund Burke III, "The Big Story: Human History, Energy Regimes, and the Environment", in idem and Kenneth Pomeranz (eds), The Environment and World History (Berkeley, CA [etc.], 2009), pp. 33-53.

68. The redistribution of colonial forest endowments usually resulted in a worsening position of the poor, if only for the loss of cheap fuel. Only the wealthier farmers had the means to buy the wood that was henceforth sold on the market; Rabindra Nath Chakraborty, "Links Between Income Distribution and Environmental Degradation in Rural India", in Stig Toft Madsen (ed.), State, Society and the Environment in South Asia (Richmond, 1999), pp. I65-199, 190.

69. See for instance Michael Mann, "Ecological Change in North India: Deforestation and Agrarian Distress in the Ganga-Yamuna Doab 1800-1850", in Richard H. Grove, Vinita Damodaran, and Satpal Sangwan (eds), Nature and the Orient: The Environmental History of South and Southeast Asia (Delhi [etc.], 1998), pp. 396-420, 398. 
Kanda's contribution deals with fuel, but also with extractive industries, or, in other words, "mining" (salt, coal). Mining ought to be another important theme in environmental history, although in few textbooks is it paid more than scant attention. ${ }^{\circ}$ Many, if not most, extractive industries all over the world have in common the fact that they were (and are) unhealthy and dangerous - and hence often carried out by slaves, convict labour (often chain gangs), corvée and other forms of compulsory labour, or by those at the bottom of the heap who have no alternatives - and that they destroy the local landscape, turning it into what is often called a "moon landscape". In addition, mining operations often poison downriver areas with the chemicals they use (for instance in gold, silver, and mercury mines) and the sludge they produce. It goes without saying that this state of affairs caused health problems among the miners and the inhabitants of adjacent areas, problems often reinforced by the creation of pockets of stagnant water, a sure source of malaria and other mosquitotransmitted diseases. ${ }^{71}$

In this volume, the contribution by Bruno also addresses the conditions under which mining took place, in this case in the Khibiny Mountains in the Soviet Union (close to the border with Finland) in the I930s. It tells the story of a group of kulaks - relatively well-off peasants, deemed class enemies by the Soviet state - who were stripped of their property, and forced to migrate to this inhospitable region, where they had to work in the apatite mines, in compulsory labour therefore. Apatite is a form of calcium phosphate which can be used to manufacture phosphate fertilizer.

The "special settlers" had to work under appalling conditions, not only because of the low temperatures, but also owing to the lack of food, proper housing, drinking water, waste disposal, and other features of elementary hygiene. This population, already quite vulnerable under "normal" circumstances, was therefore hit even harder than others when harvests in the grain-producing areas of the Soviet Union failed, as was the case in 1932-1933. Death from starvation was now added to diseases caused by malnutrition, such as scurvy and rickets. Water that had to be used for drinking, washing, and bathing was polluted with the waste products of the mines, and with human waste. Thus, the silver mines in classical Athens, the gold and coal mines in seventeenth- to nineteenthcentury Sumatra, and the apatite mines in Stalinist Russia had in common

70. For a brief overview of mining and its impact on the environment during the past two centuries, see McNeill, Something New Under the Sun, pp. 3 I-35. A recent case study is Jason W. Moore, "Silver, Ecology, and the Origins of the Modern World, I450-I640", in Alf Hornborg, J.R. McNeill, and Joan Martinez-Alier (eds), Rethinking Environmental History: World-System History and Global Environmental Change (Lanham, MD [etc.], 2007), pp. I $23-142$.

71. Radkau, Nature and Power, pp. 237, 244. 
that they were run largely by unfree labour, in addition to being a source of pollution to their natural environment, which undermined the health of the labourers.

A last theme of great importance to the environmental historian is the multifaceted role of water in history. As Bruno's contribution to this volume shows, the absence of clean, unpolluted water is a threat to human health. But even clean water can be harmful to humans, as it might be a home to mosquito larvae that could eventually turn into disease carriers, as was shown in an earlier part of this introduction. ${ }^{72}$ At the same time, water had (and has) many competing uses - it is needed for irrigation, for transport, it is a home to fish and other organisms, and it powers hydroelectric plants. ${ }^{73}$

In this volume, Nascimento and Becker sketch the development of a river system in twentieth-century Brazil, the São Francisco River Basin, from the I930s, and more in detail after c.1950. Their contribution demonstrates how population growth, urbanization, and the desire for "development" and industrialization (linked to growing global demand and supported by global capital flows) led to an emphasis on hydroelectric power plants, the construction of which competed with the river's other functions, including being a source of irrigation, a means of transportation (shipping), a spawning ground for fish, and a provider of fertile silt.

This policy obviously caused considerable environmental change, transforming the physical structure of the river bed, and the type of agriculture and livestock keeping, and therefore the landscape in the watershed area. While this policy stimulated migration of people from outside the watershed to a number of towns and cities in the region, it also drove away - or at least put out of business - small fishermen, boat and ship owners, and smallholder agriculturalists. Elsewhere, similar trends were noted: the spread of perennial irrigation strengthens the dependency on export cash crops at the expense of subsistence food crops. ${ }^{74}$

The essay by Morera also deals with water management, this time in seventeenth-century France. Here, Dutch capital (with links to the Dutch East India Company), Dutch technology (windmills), and Dutch knowhow were being employed to drain wetlands, thus stimulating local agriculture. Those who financed this enterprise obtained various rights to local lands and waters, thanks to the support of the local aristocracy-cumbureaucracy, who had a stake in the positive outcome and whose position

72. Whether irrigation furthered the spread of malaria depended on many aspects, such as the proliferation of fish and frogs that eat the larvae of the mosquito.

73. Peter H. Gleick (ed.), Water in Crisis (New York, I993); McNeill, Something New Under the Sun, pp. II8-191; Peter Boomgaard (ed.), A World of Water: Rain, Rivers and Seas in Southeast Asian Histories (Leiden, 2007).a

74. Beinart and Hughes, Environment and Empire, p. I44. 
was strengthened by these activities. This was to the detriment of many smallholder peasants and fishermen in those regions, as is shown by various recorded conflicts and law suits. The reclamation of moors and swamps became a truly global trend in the eighteenth century, stretching from Europe to China, altering physical space and reinforcing the position of local elites at the same time. ${ }^{75}$ In the French case, it was not so much a matter of global demand (although some of the products of these "polders" were exported), but of the global supply of capital in combination with the global spread of new technology and know-how.

\section{CONCLUSION}

All the contributions to this Special Issue focus on the links between environmental and social history, especially in connection with changes induced by long-term processes of globalization. Invariably, they reflect fruitful recent and ongoing research. The field is still rather young, dating largely from the past two decades, as this introduction demonstrates.

The authors illustrate the far-reaching consequences of global processes for social relations, which are not necessarily limited to the late nineteenth or twentieth centuries. Morera, for example, shows how the ruling classes in France managed to strengthen their position with the support of the networks of Dutch capitalists in the seventeenth century while thoroughly transforming the environment. In the early modern period, therefore, transnational agents also left long-lasting footprints in the environment that predisposed the position of social classes and groups. Such footprints were exceptionally large on the islands in the Caribbean and the mid-Atlantic, as Horan and Halikowski Smith make clear, although the term "ecocide" might be too strong a term to describe what happened. The notion of expanded globalization seems quite appropriate in these cases.

This volume also reveals both convergent and divergent trends in global history. Convergence was at times strong, as exemplified by Bennett (eucalypt trees being planted in several regions around the world), Morera (water management in France and Holland), Thompson (agricultural colonial policies in British colonies), Nascimento and Becker (irrigation agriculture and global consumer demands), and Halikowski Smith (sugar plantations on numerous Atlantic islands). In other cases divergence dominates, for example among the 60,000 or so salt workers of the British East India Company in Bengal, with highly localized problems and solutions to the worldwide rise in fuel prices depending upon regional environmental circumstances (Kanda's contribution). Horan notes equally different approaches and outlooks among British and French 
plantation owners in the Caribbean, although the global setting of sugar plantation slavery posed quite similar problems.

Within these different global trends transnational agents operated, at times with unintended consequences. Nascimento and Becker show how the emphasis on irrigation and hydropower rendered large groups in Brazil more disaster-prone than before by limiting their access to water resources. An increased unequal exposure to risk was encountered among the "special settlers" of the Soviet Khibiny Mountains in Bruno's contribution and the slaves on the French Caribbean plantations in Horan's article. The problems following the planting of eucalypts in South Africa, India, and Thailand shown in Bennett's article, undoubtedly another unintended consequence of conservation policies, caused the rise of social protests - protests that were also reported to have occurred after the draining of the swamps in seventeenth-century France, as Morera demonstrates.

Globalization thus not only increased the vulnerability of marginalized groups, it also fuelled the formulation of environmental concerns and the formation of environmental interest groups. In the twenty-first century, globalization continues to give rise to transnational protest, as exemplified by the Chipko movement and the plea for environmental justice gaining global dimensions. 